\section{Sarah Broadie}

\section{NATURE AND DIVINITY \\ IN PLATO'S TIMAEUS}

\section{Cambridge (Cambridge University} Press) 2012, 305 str.

Během téměř dvou a půl tisíce let, kdy je Platónův dialog Timaios vykládán, se ustavila řada témat a prŕstupů, skrze něž lze k tomuto komplikovanému dílu přistupovat. Přestože je obtížné nalézat nová východiska a argumentovat pro nové interpretace, je kniha Sarah Broadieové Nature and Divinity in Plato’s Timaeus velmi originálním interpretačním počinem. Tato originalita je jak důvodem pro to zabývat se uvedenou monografií detailněji, tak důvodem problematičnosti některých autorčiných úvah.

Knihou neprochází jedna centrální otázka či interpretační teze strukturující všechny části. Jedná se spíše o soubor sedmi víceméně samostatných studií, z nichž některé vznikly přepracováním již dříve vydaných časopiseckých článků. Jednotlivé studie mívají sice dominantní téma, avšak Broadieová probírá zároveň i celou řadu přidružených otázek, a tak je vždy výsledkem bohatý myšlenkový terén. $\mathrm{V}$ recenzi se budu soustředit pouze na hlavní linii každé studie.

První kapitola se zabývá otázkou, jaký filosofický důvod má v Timaiovi demiurgova oddělenost od světa. Tuto oddělenost není dle Broadieové možno odvysvětlit, ale je nutno ji chápat jako důležitý prvek Timaiovy kosmologie (7). ${ }^{1}$ Pokud bychom totiž demiurga nechápali odděleně, přijdeme o některé zásadní charakteristiky světa. Podle Broadieové existují dvě možnosti, jak demiurga nechápat jako odděleného od světa, obě tyto možnosti však vedou $\mathrm{k}$ nepřijatelným důsledkům. Kdyby rozum, který svět pořádá, byl imanentní látce, $z$ níž se svět skládá, přišli bychom o jednotu světa, a tím o jeho nejlepší stav. Látka je totiž roztroušená $\mathrm{v}$ prostoru, a rozum imanentní látce by tak byl rovněž roztroušený, tzn. ani by sám nebyl jednotný, ani by nejednotil svět (16). Druhou možností by byla totožnost rozumu, který pořádá svět, s rozumem světové duše. $V$ tomto případě by však Platón nemohl připsat individuálním duším odpovědnost za jejich život. Demiurg totiž tvoří mnohé části světa, zatímco duše světa má pouze jeden ,předmět", na který působí, tělo světa, a proto duše světa nemůže tvořit individuální duše (je totiž vztahem jedna ku jedné). Identita rozumu pořádajícího svět a rozumu světové duše by tak zamezila vzniku skutečně individuálních duší, nebot' duše světa nemůže být ve vztahu k ničemu jinému nežli ke svému tělu - duše ,,jednotlivců" by za této situace nebyly ničím více než částmi světové duše (19-21).

Oddělenost demiurga a světa Broadieová vykládá výhradně z perspektivy světa a jeho charakteristik. Takovýto přístup ke zkoumaným otázkám - vykládat prríčiny vzniku světa skrze jejich vztah ke světu a jeho jednotlivým aspektům - je př́tomen i v řadě jiných kapitol a ve svých komentářích se po-

1 Čísla v závorkách odkazují k paginaci recenzované knihy. 
kusím ozřejmit jistou jednostrannost takovéhoto postupu. Broadieová si primárně klade otázku po oddělenosti demiurga od světa a nikoli otázku po oddělenosti světa od demiurga, a tím pádem zdůvodňuje demiurgovu oddělenost na základě charakteristik světa. Jakkoli je tento způsob vysvětlení bezpochyby v Timaiovi prítomný, $\mathrm{v}$ řadě ohledů není dominantní - na svět se máme dívat primárně z perspektivy demiurga a nikoli na demiurga $\mathrm{z}$ perspektivy světa (Tim. 29e1 nn.). „Kosmocentrismus" Sarah Broadieové pak, domnívám se, nechává stranou klíčové ohledy Timaiovy nauky, které $\mathrm{k}$ adekvátnímu pochopení oddělenosti demiurga, respektive světa, nutně patří, především vztah demiurga a vzoru, jemuž se autorka záměrně nevěnuje. Jelikož jsou však demiurg a vzor velmi silně propojeni - poprvé se objevují v Timaiově řeči společně (Tim. 28a6b1), i demiurg je jistým vzorem pro svět (Tim. 29e2-3) -, je tematizace jejich vztahu pro pochopení oddělenosti demiurga od světa klíčová. Nejde tedy o to, že by perspektiva světa nebyla relevantní, ale nelze ji uplatňovat samostatně: Jak svět, tak demiurg mají být primárně uchopováni skrze svůj vztah $\mathrm{k}$ věčně jsoucímu vzoru.

Druhá studie se snaží ukázat důvod skrytý za Timaiovou zdánlivě řečnickou otázkou: Který vzor použil demiurg při tvorbě světa - stále totožný, nebo vzniklý (Tim. 28c5-29a2)? Důležitost použití věčně jsoucího vzoru se podle autorky ukáže, pokud promyslíme druhou variantu. Svět stvořený podle vznikajícího, tj. smyslově vnímatelného vzoru by jako celek nemohl být předmětem kosmologických úvah. Smyslovým vnímáním totiž nepozná- váme celek světa, ale vždy jen jeho části. Vzniklému vzoru, podle nějž bychom mohli uvažovat i o našem světě jako celku, se pak rovněž nemůžeme přiblížit, nebot' smyslovým vnímáním, jímž vzniklé uchopujeme, můžeme vnímat jen to, co je uvnitř našeho světa - $\mathrm{k}$ ničemu jinému smyslové vnímání nedosáhne (31-32). Stvoření našeho světa podle věčně jsoucího vzoru je tak jedinou možností, jak můžeme uvažovat o našem světě jako celku - pouze stvoření podle věčně jsoucího vzoru zakládá možnost kosmologie (33). Mírou kosmologických úvah je pak pravděpodobnost, nebot' tento svět poznáváme, nakolik je podobný svému vzoru. Pravděpodobný výklad, jímž je nutně každá kosmologie, však není pravděpodobný ve všech svých částech stejně - nacházejí se $\mathrm{v}$ něm jak části, které jsou nezpochybnitelné (např. náš svět je nejlepší z toho, co je vzniklé), tak řada částí, které připouštějí vylepšení.

Otázku, které se Broadieová věnuje v první kapitole, si Timaios explicitně neklade. Otázku diskutovanou v druhé kapitole Timaios naopak explicitně zodpovídá na řádcích $28 \mathrm{c} 5-29 \mathrm{~b} 1$. Podle Timaia je vzorem světa věčně jsoucí vzor, protože svět je nejkrásnější a demiurg nejlepší. Možnost kosmologie a obecně racionální úvahy o světě pak jistě ke kráse světa patří a v tomto smyslu není možné s autorkou nesouhlasit, když uvádí uchopitelnost světa jako důvod toho, že svět byl stvořen podle věčně jsoucího vzoru. Domnívám se však, že obdobně by bylo možno upozornit i na další aspekty krásy světa - např. na jeho kompletnost a vnitřní provázanost - a bylo by třeba strukturovaně pochopit dobrotu 
demiurga, abychom učinili zadost Timaiově vlastní odpovědi. Cílem Broadieové však není primárně pochopit Timaiovu vlastní odpověd' na otázku, kterou spolu s ním řeší, ale najít věrohodnou perspektivu, z níž bude otázka po výběru vzoru dávat smysl. Jakkoli pak perspektivu, již autorka nabízí, pokládám za zajímavou a nosnou, postrádám $\mathrm{v}$ této kapitole větší snahu pochopit a vytěžit Timaiovu vlastní odpověd'.

Vztahem kosmologie a metafyziky se zabývá třetí studie, v níž si Broadieová klade otázku, zda je správné číst Timaia primárně jako kosmologický výklad, do něhož je metafyzika jakousi vstupní branou, nebo jako cestu k metafyzice, jež vede skrze kosmologii. Ačkoli podle autorky některá místa dialogu svědčí pro druhou variantu, první varianta je podepřena silnějšími argumenty: Deklarovaným cílem Timaiovy řeči je vznik světa; kosmologie je sice popsána jako cesta $\mathrm{k}$ něčemu dalšímu, tím dalším však není metafyzika, ale ideální obec $\mathrm{v}$ pohybu; Timaiův popis fenoménů tohoto světa jde daleko za rámec toho, co je potřebné pro výstup $\mathrm{k}$ metafyzice; a konečně, Timaios explicitně popírá, že by kosmologické zkoumání mohlo být cestou $\mathrm{k}$ principům veškerenstva (61). Pro autorku přitom není rozlišení mezi metafyzickým a kosmologickým čtením pouze otázkou důrazů, ale má velký dopad na pochopení toho, jaký vzor vyžaduje a předkládá Timaiova řeč. Dle Broadieové totiž není správné chápat vzor v Timaiovi jako př́klad, jehož kopírováním vzniká svět, ale je spíše plánem či návodem pro stvoření světa (73-74). Tento plán čerpá svůj smysl z produktu, kterým náš svět je, a nemá jiná samostatná určení. Z hlediska epistemologie i kosmogonie je tedy v Timaiovi vzor podřízen světu.

Jak uvádí sama Broadieová, kosmologický důraz Timaia není spornou naukou - Timaios se věnuje převážně světu, jeho příčinám a jeho částem. Značně kontroverzním je až pojetí vzoru, které autorka Timaiovi přičítá. Její tvrzení, že vzor je v Timaiovi třeba chápat ve vztahu ke světu jakožto návod pro jeho stvoření, jde proti tradiční interpretaci, podle níž je vzor samostatný a jeho smysl není redukovatelný na tvoření světa. Návod bez realizace totiž postrádá smysl, vzor je však představován jako svébytná oblast (věčně jsoucí, stále totožná), u níž se spíše klade otázka po arbitrárnosti jejího napodobení nežli otázka po jejím samostatném smyslu. Abychom chápali, čím svět je, musíme chápat jeho vztah ke vzoru. Abychom však chápali vzor, nemusíme, alespoň nikoli primárně, chápat jeho vztah ke vznikajícímu světu. Broadieová uznává, že Timaios pronáší i výroky, které vyjadřují samostatnost vzoru, avšak považuje je v zásadě za Platónův omyl nedomyslel, $\mathrm{k}$ jakému pojetí vzoru ho takovéto výroky zavazují (73). Jakkoli chápu potřebu promýšlet smysl světa a jeho stvoření i z jiné perspektivy, nežli je perspektiva tvoření napodobeniny podle vzoru, napodobeniny, která je ze své povahy méně dokonalá nežli vzor, autorčiny úvahy, domnívám se, postupují př́liliš rychle $\mathrm{k}$ př́liš radikálním závěrům. V rámci vyzdvihování svébytnosti světa v Timaiovi autorka potlačuje svébytnost vzoru - to však, domnívám se, není ani jediná možnost pro pochopení samostatného smyslu světa (svět může doplňovat vzor, po- 
dle nějž je stvořen, o nový a na vzor neredukovatelný smysl), ani tím není učiněno zadost mnoha Timaiovým výrokům o povaze vzoru.

Ve čtvrté kapitole se autorka snaží vysvětlit důležitost smrtelných bytostí $\mathrm{v}$ rámci celku světa. Tuto problematiku specifičtěji uchopuje pomocí otázky po významu vtělení rozumu do smrtelného živočicha. Podle autorky je zřejmé, že vtělení rozumu není důsledkem chyby či selhání - jak by se mohlo zdát z mýtu o vozataji a dvojspřeží z Faidra -, ale je vetknuto do mnoha částí Platónovy kosmologie: K tomu, aby svět byl vnímatelný, což je jeho základní charakteristika, je třeba smrtelných bytostí schopných vnímání; bohové tvoří smrtelná těla s ohledem na to, že v těchto tělech bude rozumná duše; duše je před svým vtělením připravována na vstup do těla $(91,107)$. Co podstatného však světu přináší fakt, že rozum je vtělen do smrtelného těla jako do nepřátelského prostředí a že mu jsou dány prostředky, aby se $\mathrm{v}$ tomto nepřátelském prostředí nemusel nadobro ztratit? Proč bohové stvořili takovouto nemoc a zároveň dali člověku lék proti ní? Podle autorky by bez vtělení rozumu do smrtelného těla nebyl možný specifický způsob vlády rozumu - ten způsob, který lze charakterizovat jako sebe-vývoj rozumu (90). Tento sebe-vývoj pak vytváŕí zcela novou oblast etického a kulturního vývoje, který je podstatně odlišný od přírodních procesů. Přírodní procesy se totiž dějí vždy stejně, zatímco člověk se v oblasti etiky a kultury za stejných okolností stejně nerozhoduje. Bez vtělení rozumu do smrtelných těl by tato oblast vlády rozumu neexistovala (106).
Sebe-vývoj rozumu jako důvod existence smrtelných bytostí obdařených rozumem je, domnívám se, nosný koncept. Úvahu Sarah Broadieové by snad bylo možné rozšíríit následujícím způsobem. Existence smrtelných živočichů je v Timaiovi zdůvodňována prostřednictvím faktu, že ve vzoru, jehož je svět napodobeninou, je prítomen nejen rod bohů, ale i trojí rod smrtelných bytostí. Aby smrtelné bytosti vznikly, nesmí být stvořeny pouze demiurgem, nebot' pak by se rovnaly nesmrtelným bohům. Na jejich vzniku se musí zásadním způsobem podílet i bohové. Smrtelné bytosti jsou proto stvořeny jako duše vtělené do smrtelného těla přičemž nesmrtelnou část jejich duše tvoří demiurg, zatímco smrtelné části duše i celé tělo tvoří demiurgem stvoření bohové - a jako takové činí tyto bytosti svět kompletním (Tim. 41b7-e4). Perspektiva rozumu je sice pro smrtelné bytosti vůdčí, neměli bychom však přehlížet celkovost Timaiova zdůvodnění existence smrtelných bytostí. V ní nejde pouze o vystavění podmínek pro specifický život rozumu - pro život rozumu ve smrtelném těle -, ale jde rovněž o co nejlepší stav tělesného, který je dle Timaiových vlastních slov vždy lepší s rozumem nežli bez něj (Tim. 30b1-6). Jakkoli je tato perspektiva na některých místech potlačována a na tělo smrtelných bytostí je pohlíženo jako na služebnictvo uzpůsobené vládě rozumu (Tim. $44 \mathrm{~d} 3 \mathrm{nn}$.), uzpůsobování tělesného skrze připojení rozumu je v Timaiovi rovněž velmi vlivný způsob popisu vzniku světa, a je potřeba ho při úvahách o smyslu smrtelných bytostí zohlednit.

Pátá kapitola je věnována především rámcovému Kritiovu vyprávění 
(Tim. 20d7-26e1) a jeho významu. Hlavní výkladová strategie této rozsáhlé studie je založena na argumentu ex silentio. Ze skutečnosti, že Kritias nezmiňuje bitvu u Marathónu, která byla v době sepsání dialogu Timaios považována za př́klad slavného athénského vítězství, Broadieová za pomoci několika podpůrných argumentů vyvozuje, že příběh o athénském vítězství nad Atlantidou je fikcí a že je koncipován tak, aby na čtenáře dialogu jako fikce působil. $Z$ napětí mezi fikčním bojem s Atlantidou a skutečnou, ale zamlčenou bitvou u Marathónu pak Broadieová vyvozuje několik interpretačních tezí o správnosti idealizování historických, či pseudohistorických událostí.

Šestá studie je věnována otázce, jaký význam v Timaiovi př́sluší živlům a látce obecně. Autorka upozorňuje, že na rozdíl od Faidóna, ve kterém látka nemá funkci příčiny, ale pouze nutné podmínky, je látka v Timaiovi jako prričina uznána, byt' jako příčina pomocná (176). Bez látky tak nelze plně pochopit příčiny jednotlivých jevů ve světě: např́klad vidění není možné dostatečně popsat jako funkční strukturu uchopitelnou v abstraktních termínech a realizovatelnou $\mathrm{v}$ různých materiálech. Pochopení prríčin vidění zahrnuje pochopení ohně a jeho role (181). Pokud však má látka takovýto vliv na podobu světa, co zaručuje, že umožní vznik nejlepšího možného světa? Aby látka nestála v cestě nejlepšímu uspořádání, Timaios dokazuje její nesamostatnost a spř́zněnost se vzorem pomocí konceptu třetího rodu (234). Látka totiž není ničím samostatným, ale je třetím rodem určeným na základě vzoru, je obrazem vzoru. Smyslem třetího rodu tak není rešit obecné problémy vztahu idejí a vznikání, ale její smysl je specificky kosmologický, má totiž ukázat poddajnost látky vůči nejlepšímu možnému uspořádání. Ostatní charakteristiky třetího rodu nejsou podle autorky podstatné (241-242).

Třetí rod, nutnost a prekosmické vznikání jsou koncepty, které hrají v Timaiovi klíčovou roli, zatímco v jiných dialozích se bud'to nevyskytují vůbec, nebo jsou probírány podstatně méně podrobně. Role těchto prvků $\mathrm{v}$ rámci tvoření nápodoby věčně jsoucího vzoru je předmětem mnoha kontroverzí, ${ }^{2}$ přičemž Broadieová zastává $\mathrm{v}$ tomto kontextu poněkud přkkvapivé stanovisko. Jednak totiž tvrdí, že bez popisu látkovosti a pouze $\mathrm{z}$ účelu (funkce) našeho světa nepochopíme dostatečně náš svět, zároveň však upozorňuje, že látka neklade tvoření světa žádný odpor, tj. neomezuje nejlepší napodobení věčně jsoucího vzoru. Standardní interpretace vyzdvihující význam látky (případně třetího rodu či nutnosti) prritom pracuje s tím, že látka je důležitá právě proto, že vytvář́ jisté limity, které napodobení vzoru nemů-

2 Viz např. A. Gregory, Aristotle and Some of His Commentators on Timaeus' Receptacle, in: R. W. Sharpless - A. Sheppard (vyd.), Ancient Approaches to Plato's Timaeus, London 2003, str. 29-47. D. Miller, The Third Kind in Plato's Timaeus, Göttingen 2003. F. M. Cornford, Plato's Cosmology: The Timaeus of Plato, Cambridge (Ind.) 1997 (repr.), str. 159-177. 
že překročit. ${ }^{3}$ Jak přesně ony dvě teze, které Sarah Broadieová zastává a které nejdou tradičně ruku $\mathrm{v}$ ruce, drží dohromady, však není z kapitoly jasné.

Má druhá poznámka $\mathrm{k}$ této kapitole se týká interpretační perspektivy, s níž jsme se v knize setkali již dř́ve. Tak jako v první a třetí studii vykládala autorka z perspektivy světa demiurga a vzor, $v$ této studii vykládá $\mathrm{z}$ perspektivy světa třetí rod a tvrdí, že ten je pouze jakýmsi rétorickým nástrojem, jehož prostřednictvím Platón ukazuje poddajnost látky vůči nejlepšímu možnému uspořádání. Tuto interpretaci nepovažuji za udržitelnou. Třetí rod je totiž konstitutivní pro vznikání, je matkou a chůvou všeho vznikání, a vznikání, tj. i látka, je na třetím rodu závislé. Domnívám se tedy, že nelze, jak činí Broadieová, takovéto popisy třetího rodu upozadit, odejmout jim kosmologické a ontologické významy a učinit je pouhým nástrojem výkladu.

Poslední, sedmá kapitola se zabývá otázkou, která je v souvislosti s Timaiem diskutována pravděpodobně nejvíce: Je třeba vykládat Timaiův popis vzniku světa doslovně, nebo nikoli? Pokud bychom odstraněním proto-historického popisu (čas vzniká až se světem, a proto se nejedná o historii, ale o jakousi proto-historii) ztratili nějaký podstatný rys světa, je třeba, jak se autorka domnívá, přijmout doslovný výklad popisu vzniku světa. Broadieová uvádí tři rysy světa, nad nimiž se $\mathrm{z}$ této perspektivy zamýšlí. Jak popis vzniku světa $\mathrm{z}$ neuspořádaného materiálu, tak popis tvoření světa v několika postupných fázích lze podle ní vyložit bez předpokladu, že jde o popis reálného vzniku světa, aniž bychom přitom nutně přišli o nějaké obsahově relevantní určení světa (249-255). V př́ípadě dokončení božského utváření světa před nějakou dobou však jde o rys, který není jen záležitostí způsobu výkladu

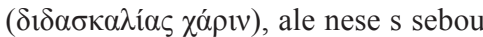
důležitý obsah, který není možno vyjádřit odlišně. Tento rys popisu vzniku světa totiž odděluje božskou zakládající aktivitu a přirozený běh světa, do kterého bůh již nezasahuje. Pokud bychom tento rozměr výkladu odebrali, přršli bychom bud'to o božské založení světa, nebo o koncepci, podle níž př́roda a jednotlivé živé bytosti vedou samy své činy. Jakkoli tedy některé části Timaiova výkladu podporují nedoslovný výklad vzniku světa, tento důležitý ohled svědčí, podle autorky, pro výklad doslovný.

S autorkou nelze než souhlasit, že samostatnost přirozeného běhu světa je součástí úmyslu, s nímž demiurg svět tvoří. Zatímco nesmrtelné bytosti tvoří demiurg sám tak, že jim náleží dokonalý kruhovitý pohyb, vytváření smrtelných bytostí má dvojí původ - jejich nesmrtelnou část tvoří demiurg sám, smrtelné části pak vytvářejí nesmrtelní bohové, nebot' demiurg sám nemůže nic smrtelného stvořit. Samostatnost světa je tak součástí demiurgova záměru realizovaného jak prímo, tak zprostředkovaně. Tato samostatnost pak, domnívám se, stojí na některých základních strukturách, které svět sám

3 Viz např. G. R. Morrow, Necessity and Persuasion in Plato's Timaeus, in: The Philosophical Review, 59, 1950, str. 147-163. 
nevytváří ani neudržuje. Vše tělesné je závislé na stabilitě základních trojúhelníků, vše duševní pak na stabilitě směsi totožnosti, různosti a jsoucnosti. Co tuto stabilitu základních struktur zajišt’uje? Nebylo by třeba chápat samostatnost světa tak, že v něm demiurg udržuje tyto základní struktury stále, a tím umožňuje relativní samostatnost života světa? Není přiměřenější Timaiově nauce i některým explicitním výrokům z dialogu považovat jisté stálé demiurgické působení za nutnou podmínku určité samostatnosti světa? Je zřejmé, že mnoho míst dialogu hovoří velmi explicitně o ukončení některých demiurgových činností (např̀. Tim. 36d8-e1,42e5-7, 53b1-5). Systematická úvaha o samostatnosti světa, kterou Broadieová předkládá, však, zdá se mi, otevírá prostor nejen pro doslovné čtení vzniku světa, ale i pro úvahu o podmínkách samostatnosti světa a jejich příčinách.

Kniha Nature and Divinity nemá jedno centrální téma. Jak jsem však již upozornil, v řadě studií využívá podobné výkladové východisko. Principy, které vysvětlují vznik a podobu našeho světa, Broadieová interpretuje právě z hlediska světa. Tímto prismatem tak vykládá demiurga, vzor i příjemkyni. V prŕípadě demiurga nejde autorka dále nežli právě k jeho vylíčení z perspektivy světa (kap. 1). V prŕípadě vzoru a příjemkyně však argumentuje pro pozici, podle níž je neadekvátní pohlížet na tato dvě témata jinak nežli z perspektivy jejich vztahu a prrínosu pro vzniklý svět (kap. 2 a 6). Takovýto pohled je značně problematický. I v samotném Timaiovi klade Platón důraz na samostatnost vzoru a nesamostatnost vznikání, přričemž - jak se domnívám - autorčina interpretace, podle níž je vzor především návodem na vytvoření světa, převrací vlastní Timaiův důraz. Př́ijemkyně je podle Broadieové pouhým nástrojem k předvedení poddajnosti vznikání vưči nejlepšímu možnému uspořádání, nic více za ní hledat nemáme. Takovýto postoj, zdá se mi, nepřiměřeně umenšuje význam př́jemkyně, který, jakkoli je v detailech nejasný, hraje celkovější roli v ontologickém rozvrhu prezentovaném v Timaiovi.

Kniha Sarah Broadieové není vhodným úvodem do problematiky Platónova Timaia. Je nicméně velmi inspirativním čtením. Nikoli proto, že by výsledky, k nimž dospívá, bylo možno brát za bernou minci, ale díky tomu, že čtenáře nutí dívat se na text $\mathrm{z}$ dosti netradiční perspektivy a zahlédnout $\mathrm{v}$ něm i motivy, které $\mathrm{v}$ tradičnějších interpretacích povětšinou zůstávají stranou zájmu. ${ }^{4}$

Ondřej Krása

4 Tato recenze byla podpořena v rámci projektu OP VVV „Centrum pro etiku jako studium hodnoty člověka“, reg. č. CZ.02.1.01/0.0/0.0/15 003/0000425 spolufinancovaného z Evropského fondu pro regionální rozvoj a státního rozpočtu České republiky. 